\title{
STIMULATION DEMAND CHARACTERISTICS OF THE STUDENTS OF THE POLISH AIR FORCE ACADEMY IN DĘBLIN
}

\author{
Anna JĘDRYCH, Małgorzata KRZYWNICKA \\ Cardinal Stefan Wyszyński University, Aviation and Space Psychology Division of the Psychology Students' \\ Research Association, Warsaw
}

Source of support: Own sources

Author's address: Anna Jędrych, Aviation and Space Psychology Division of the Psychology Students' Research Association, Cardinal Stefan Wyszyński University in Warsaw, Poland, e-mail: skplik.uksw@gmail.com

Introduction: According to Marvin Zuckerman's theory, sensation seeking is defined as the need for stimulation required to maintain the optimum level of arousal. The goal of this study is to characterize the stimulation requirements manifested by sensation seeking in the officer cadets of the Polish Air Force Academy in Dęblin (PAFA) and to compare these requirements to those of the students of other technical universities.

Methods: The study was conducted in a group of 23 officer cadets of PAFA, aged 20-23 years, and a group of 25 students of other technical universities. The stimulation demand was measured using the Sensation Seeking Scale (SSS) developed by Marvin Zuckerman.

Results: Studies revealed that the officer cadets required more stimulation (sensation seeking) than the students of other technical universities.

Conclusions: Pilots are characterized by higher demand for stimulation, which may be one of the components involved in motivation for a stress-related occupation.

Keywords: Zuckerman's Sensation Seeking Scale (SSS), stimulation demand, sensation seeking, students, military aviation

Table: 1 - References: 4 • Full-text PDF: http://www.pjamp.com • Copyright (C 2013 Polish Aviation Medicine Society, ul. Krasińskiego 54/56, 01-755 Warsaw, license WIML • Indexation: Index Copernicus, Polish Ministry of Science and Higher Education 


\section{INTRODUCTION}

The groundwork of Marvin Zuckerman's sensation seeking theory was laid by sensory deprivation studies and analyses conducted by Hebb or Berlyne as well as by studies on the temperament conducted by Gray or Eysenck [1].

Sensation seeking, defined by Marvin Zuckerman as a "sensory requirement based on the optimum level of arousal" is a trait reflecting individual's tendency to seek diverse, novel, complex and intense sensations and experiences as well as their readiness to take up risks [2]. Sensation seeking is a structure consisting of four different factors rather than a single general trait. The component factors include:

- thrill and adventure seeking (TAS) - manifested by the passion for outdoor activities, physically risky activities, and engagement in sports providing high levels of excitation (e.g. skiing);

- experience seeking (ES) - related to experiences associated with mental and sensory activation or the choice of non-conformist lifestyles (e.g. unplanned travels);

- disinhibition (DIS) - most strongly determined by biological factors, manifested by a tendency towards emotional discharge and seeking relaxation in such behaviors as drinking, gambling, etc.;

- boredom susceptibility (BS) - associated with aversion to repeatable experiences, routine work, or boring people, manifested by anxiety as a response to monotony.

In addition, the sensation seeking requirement is strongly determined by biological factors. It is relatively stable, thus explaining differences between individuals and presenting features of psychological trait rather than psychological condition. The optimum level of arousal is signaled as a positive emotional condition, suggesting that emotional conditions could be the key to understanding some behavioral choices [1].

According to Zuckerman's theory, glaring differences can be observed between individuals with regard to sensory deprivation. Individuals with high stimulation demand usually perceive the risks to be lower, experience lower levels of anxiety, are more impulsive, may experience various types of tension, poorly respond to routine situations and require to continuously seek for novelty. On the other hand, individuals with low stimulation demand usually perceive the risks to be higher, experience higher levels of anxiety, are less impulsive, more withdrawn and timid. Numerous significant differences may be observed between students of different specialties in terms of the sensation seeking trait [4].

The goal of this study is to demonstrate such potential differences in sensation seeking between the students of PAFA and students of other technical universities.

\section{METHODS}

The study was conducted in a group of 23 officer cadets of PAFA, aged 20-23 years, and a group of 22 students of other technical universities, including Warsaw University of Technology, Military University of Technology, and Warsaw University of Life Sciences, aged 19-24 years. The stimulation demand was measured using the Sensation Seeking Scale (SSS) developed by Marvin Zuckerman. The Polish version of the tool consists of 5 subscales:

- General Stimulation Demand Scale (G)

- Thrill and Adventure Seeking Scale (TAS): related to the willingness to experience danger, engage in risky, exciting activities, such as skiing or parachuting;

- Experience Seeking scale (ES): related to the search for experiences associated with mental and sensory activation or the choice of nonconformist lifestyles (e.g. unplanned travels, illicit drugs);

- Disinhibition Scale (DIS): most strongly determined by biological factors, manifested by a tendency towards emotional discharge and seeking relaxation in such behaviors as drinking or gambling;

- Boredom Susceptibility Scale (BS): associated with aversion to repeatable experiences, routine work, or boring people, manifested by anxiety as a response to monotony. An additional scale was also used in the Polish version of the tool, i.e.

- I Scale: reflecting the demand for intellectual and cognitive stimulation.

\section{RESULTS}

The hypothesis of the presence in stimulation demand between the study groups was verified by Student's t-test (parametric test for two independent samples). The compared groups were equivalent in numbers.

The table below (Tab. 1.) compares the results obtained by the PAFA students and the students of other technical universities with respect to the individual traits comprising the stimulation demand. 
A. Jędrych, M. Krzywnicka - Stimulation demand...

Tab. 1. Student's independent sample t-test comparison of PAFA students and students of other technical universities with respect to stimulation demand (using individual subscales of the Sensation Seeking Scale).

\begin{tabular}{|c|c|c|c|c|c|c|c|}
\hline $\begin{array}{l}\text { Sensation Seeking } \\
\text { Factor }\end{array}$ & Academy & Mean & $\mathbf{F}$ & Significance & $\mathbf{t}$ & df & $\begin{array}{l}\text { Significance } \\
\text { (double-sided) }\end{array}$ \\
\hline \multirow{2}{*}{$\begin{array}{l}\text { General Stimulation } \\
\text { Demand (G) }\end{array}$} & PAFA & 11.48 & \multirow{2}{*}{2.618} & \multirow{2}{*}{0.113} & \multirow{2}{*}{1.059} & \multirow{2}{*}{42} & \multirow{2}{*}{0.296} \\
\hline & Other & 10.43 & & & & & \\
\hline \multirow{2}{*}{$\begin{array}{c}\text { Thrill and Adventure } \\
\text { Seeking (TAS) }\end{array}$} & PAFA & 10.48 & \multirow{2}{*}{0.949} & \multirow{2}{*}{0.335} & \multirow{2}{*}{0.929} & \multirow{2}{*}{43} & \multirow{2}{*}{0.358} \\
\hline & Other & 9.64 & & & & & \\
\hline \multirow{2}{*}{$\begin{array}{l}\text { Experience Seeking } \\
\text { (ES) }\end{array}$} & PAFA & 7.39 & \multirow{2}{*}{3.301} & \multirow{2}{*}{.076} & \multirow{2}{*}{.869} & \multirow{2}{*}{43} & \multirow{2}{*}{.390} \\
\hline & Other & 6.68 & & & & & \\
\hline \multirow{2}{*}{ Disinhibition (DIS) } & PAFA & 8.87 & \multirow{2}{*}{4.349} & \multirow{2}{*}{.043} & \multirow{2}{*}{.892} & \multirow{2}{*}{43} & \multirow{2}{*}{.377} \\
\hline & Other & 7.91 & & & & & \\
\hline \multirow{2}{*}{$\begin{array}{l}\text { Boredom suscepti- } \\
\text { bility (BS) }\end{array}$} & PAFA & 8.87 & \multirow{2}{*}{.886} & \multirow{2}{*}{.352} & \multirow{2}{*}{.545} & \multirow{2}{*}{43} & \multirow{2}{*}{.589} \\
\hline & Other & 8.23 & & & & & \\
\hline \multirow{2}{*}{$\begin{array}{l}\text { Additional subscale } \\
\text { (I) }\end{array}$} & PAFA & 5.17 & \multirow{2}{*}{6.891} & \multirow{2}{*}{.012} & \multirow{2}{*}{2.243} & \multirow{2}{*}{43} & \multirow{2}{*}{.030} \\
\hline & Other & 4.18 & & & & & \\
\hline
\end{tabular}

The independent samples t-test analysis revealed that the only statistically significant difference between the PAFA students and the students of other technical universities was that related to the additional subscale (I). PAFA students scored higher in the additional subscale I as compared to the students of other technical universities: $t(43)$ $=2.243 ; p<0.05$. Aviation students were found to be characterized by higher demand for intellectual and cognitive stimulation than the students of other technical specialties. Differences in the remaining subscales were statistically insignificant. This means that both study groups, i.e. the PAFA students and the students of other technical universities, differed only slightly in terms of the willingness to experience danger, engage in risky, exciting activities, seek sensations associated with activation of brain and senses and choose nonconformist lifestyles, as well as of the tendency to discharge and aversion to boredom and routine.

The occupation of a pilot is difficult, stressful and imposing much responsibility. Pilots are require to react quickly and resolutely, make apt decisions, be aware of their responsibility andcapable to act under the pressure of time as well as cope with the burden associated with intellectual cognitive processes. In face of these requirements, pilots are subjected to significant burden, both intellectual and cognitive. Therefore, the best pilots are individuals with high demand for the specific kind of stimulation, i.e. intellectual and cognitive stimulation [3].

\section{CONCLUSIONS}

1. Significant differences in sensation seeking were observed between the students of PAFA and students of other technical universities at the level of intellectual and cognitive stimulation, which was higher in PAFA students compared to the students of other technical specialties.

2. No differences were observed between the PAFA students and the students of other technical universities in terms of general stimulation demand.

3. Pilots are characterized by higher demand for intellectual and cognitive stimulation, which may be one of the components involved in motivation to take up this highly stimulative occupation.

\section{AUTHORS' DECLARATION:}

Study Design: Anna Jędrych, Małgorzata Krzywnicka; Data Collection: Anna Jędrych, Małgorzata Krzywnicka; Statistical Analysis: Anna Jędrych, Małgorzata Krzywnicka; Manuscript Preparation: Anna Jędrych, Małgorzata Krzywnicka; Funds Collection: Anna Jędrych, Małgorzata Krzywnicka. The Authors declare that there is no conflict of interest. 
Students' corner

\section{REFERENCES}

1. Gasiul H. Teorie emocji i motywacji. Warsaw: UKSW; 2007.

2. Strelau J. Psychologia temperament. Warsaw: PWN: 2001.

3. Terelak JF, Kobos Z, Truszczyński O, Tarnowski A, Maciejczyk J. Piloci. In: Terelak JF, ed. Stres zawodowy: Charakterystyka psychologiczna wybranych zawodów stresowych. Warsaw: Wyd. UKSW; 2007:333-82.

4. Zuckerman M. Sensation seeking and risk taking. In: Izard CE, ed. Emotions in personality and psychopathology. New York, London: Plenum Press; 1997:163-197.

Cite this article as: Jedrych A, Krzywnicka M. Stimulation Demand Characteristics of the Students of the Polish Air Force Academy in Deblin. Pol J Aviat Med Psychol, 2013; 19(4):31-34. 